\title{
Exploration of Youth Characteristics on the Adoption of the Subang Batik Tourism Village Innovation
}

\author{
Iip Saripah*, Jajat S. Ardiwinata, Nike Kamarubiani, Mohamad Hadi Ali Mutamam, Retno Dwi Lestari, Ari Putra \\ Community Education \\ Universitas Pendidikan Indonesia \\ Bandung, Indonesia \\ *iip.saripah@upi.edu, jsardipls@upi.edu,nike.kamarubiani@upi.edu,mohamad_mutamam@upi.edu, \\ retnooodwilestari@gmail.com, arie_poetra67@yahoo.co.id
}

\begin{abstract}
Changes in the situation, a health pandemic, and the low level of innovation among the youths threaten the sustainable development of the Subang Batik Tourism Village. Youth personality variables have a different impact on innovation adoption which can be used as a reference in designing innovative attitude training. Literature review is seen from the personality variables which include demographic, social, and economic characteristics of innovation adoption. This study identifies with the Kruskall Wallis significance test approach to see the differences in personality variables on the characteristics of innovation adoption. In addition, this study uses an exploratory approach from interview results to map the causes of the low adoption of innovation. The results showed that education from the social side and income from the economic side had differences in innovation adoption. Education provides two important roles. First, related to expertise in launching different ideas. Second, related to one's ability to cope with environmental changes and competition. From the income side, income expectations are one of the reasons someone makes an innovation to solve problems. This study also found that limited access to capital had a significant impact on the low launch of new ideas in the development of the Subang Batik Tourism Village. This research can be used as initial research to develop innovative youth training designs. This is important considering that innovation and youth are part of education for adults.
\end{abstract}

Keywords-personality variables, innovative youth, Batik Subang

\section{INTRODUCTION}

Interest in cultural tourism, the characteristics of local residents, and environmental quality are important parts of the analysis of tourism demand models [1]. Each region is competing in encouraging the development and management of tourism that can provide economic and social benefits, as well as protect and enhance cultural values. Therefore, the development of a tourism village is a strategic step in managing cultural potential and improving the quality of human resources.
In the concept of a tourism village, every level of society must be able to be actively involved, including being able to motivate each other, face challenges, and solve existing problems. In the preliminary study, innovative attitudes have emerged in the community elements of the Subang Batik Tourism Village. Yayat Ruhyat and Azhar Syhara, two young pioneers of Batik Subang and the founder of the Creative Community Empowerment Movement Group (Kelompok Penggerak Pemberdayaan Masyarakat Kreatif or KPPMK), managed to get the confirmation of the motif gaganasan and padi as the Batik Subang motif [2]. Through KPPMK, various activities such as training, an information center, as well as the maturation of ideas to build an object for the Subang Batik Tourism Village are carried out by mobilizing the participation of all elements of society. The youths are trained to make batik Subang, to know the concept, reasons, and benefits of developing batik subang. Another motive was created in this KPPMK activity, namely the papaisan motif as a motive that emerged from the traditional culinary wealth of the Subang community.

As a tourism village that has just been pioneered, Batik Subang Tourism Village does not yet have sufficient systems and networks to build its potential. This condition is faced with the Covid-19 pandemic which has caused all activities to stop since early March 2020. Tourists have also stopped visiting the Subang Batik Tourism Village area due to the large-scale social restrictions (Pembatasan Sosial Berskala Besar or PSBB) policy in a number of areas.

The cessation of various activities in the Subang Batik Tourism Village caused the number of requests for more than 500 copies of batik to be unable to be fulfilled. In addition, the PSBB stopped the income from tourist visits to the Subang Batik Tourism Village which was used as operational costs.

On the other hand, the current state of the health pandemic is a new condition that hardly takes into account the risks and solutions. However, the stagnant conditions that occurred in KPPMK indicated that the training and stimulus carried out were still in the nature of elaborating activities based on 
predicted learning needs. Although $88.2 \%$ of KPPMK participants have participated in the batik Subang training, but innovation still comes from the founders, it has not penetrated every element of the social system's mind. Respondents tend to passively wait for conditions to return to normal to develop the Subang Batik Tourism Village.

Innovative Youth Training Modeling is needed as an effort to raise awareness to do something together in solving a condition. Training activities are carried out deliberately, organized, and systematically to provide and improve knowledge and skills in a relatively short time by prioritizing practice, in order to gain knowledge, attitudes and skills in understanding and carrying out a job effectively and efficiently [3]. Designing a training model requires some preparation regarding inputs, processes and outputs. One of the things related to input is personality variables. This also applies to the diffusion of innovation. Based on Rogers [4], socioeconomic status, in this study referred to as personality variables, provides different attitudes in appreciating information as a factor for doing something better. The information obtained is an important element in decision making. A person who has a higher socioeconomic status can devote himself in terms of time and energy to obtain information [4]. Therefore, the mapping of personality variables is important in relation to the adoption of innovations that can be used as a reference for designing innovative youth training models.

From the description above, the problem framework, then the hypothesis of this study is that there is a difference between demographic characteristics and the adoption of innovation in the Subang Batik Tourism Village.

\section{MethodS}

The method used in this study is survey. The questionnaire was processed using the Kruskall Wallis significance test approach to see the differences in personality variables on the characteristics of innovation adoption. Researchers compared personal factors based on socio-economics to innovation adoption. These factors include demographic, social and economic factors. Demographic Incomplete sentence characteristics, including the generation and number of children. On the social side, there are marital status and education. Finally, in the economy, including work, number of dependents in the family, and income. Meanwhile, innovation adoption variables include communication channels, relative benefits, and complexity.

The analysis was determined based on the normality of the data. Test data normality using lilliefors. The test results show that the data distribution is not normal, so the analysis uses kruskal wallis. The basis for decision making is by comparing the significance value (Asymp.Sig) with a probability of 0.05 . The decision making provisions are as follows:

- if the Asymp.Sig value> 0.05, there is no difference or $\mathrm{HO}$ is accepted

- if the Asymp.Sig value $<0.05$, then there is a difference or $\mathrm{H} 0$ is rejected.
This data was obtained from questionnaires distributed to KPPMK members. There were 17 respondents from a population of 20 participants. Taking into account that the maximum error rate in social science is $5 \%(0.05)$, then based on the Slovin formula, the sample has approached the minimum value. The considerations are as follows:

$$
\begin{aligned}
& n=\frac{19}{1+\mathrm{Ne} 2}=\frac{19}{1+(19) \cdot(0,05 \times 0,05)}=\frac{19}{1,047}=18,14 \approx 18 \\
& \text { description: } \\
& \begin{array}{ll}
\mathrm{n} \quad=\text { Sample } \\
\mathrm{N} \quad=\text { Population } \\
\mathrm{e} \quad=\text { Error Rate }
\end{array}
\end{aligned}
$$

The data is derived from questionnaire, namely data collection techniques done by way of giving a set of questions or a written statement to the respondent to answer [5]. The questionnaire was used for data on Innovation Adoption Characteristics (Y) and Personality variables (X). The questionnaire in this study used a closed questionnaire for the following reasons: 1) so that the results of the questionnaire were easy to process, coded, and scored, 2) efficient in filling out the questionnaire, 3) hope that the filling was easier for respondents. The questionnaire contains 12 statements

\begin{tabular}{|c|c|c|}
\hline Variable & Indicator & Code \\
\hline \multirow[t]{3}{*}{$\begin{array}{l}\text { Adoption of } \\
\text { Innovations }\end{array}$} & $\begin{array}{ll}\text { 1.1.1 } & \text { Communication Channels } \\
\text { 1.1.1.1 } & \text { Mass Media } \\
\text { 1.1.1.2 } & \text { Interpersonal Channels } \\
\end{array}$ & Y1 \\
\hline & $\begin{array}{ll}\text { 1.1.2 } & \text { Relatives Advantages } \\
\text { 1.1.2.1 } & \text { Financial Profits } \\
\text { 1.1.2.2 } & \text { Social } \\
\text { 1.1.2.3 } & \text { Satisfaction } \\
\end{array}$ & $\mathrm{Y} 2$ \\
\hline & 1.1.3 Complexity & Y3 \\
\hline Personality & $\begin{array}{l}\text { 1.1.4 Socio-Economic Characteristic } \\
\text { 1.1.4.1 Demographics } \\
\text { 1.1.4.2 Social } \\
\text { 1.1.4.3 Economy }\end{array}$ & $\mathrm{X} 1$ \\
\hline
\end{tabular}
regarding the Characteristics of Innovation Adoption (Y), and 8 questions for personality variables (X).

The instrument grid is shown in Table 1.

TABLE I. RESEARCH GRID

Interviews were conducted to determine the causes and conditions of the field. The technique of collecting data by face to face with the founder of KPPMK in order to obtain complete and in-depth [6] was carried out on September 1, 2020. The collected data was then explored which is part of a qualitative approach in social science to support research in the field of culture. and social phenomena that serve to gain a deep understanding of the object of research [7].

\section{RESULTS AND DISCUSSION}

The innovative attitude formation training model offers a training alternative whose long-term goal is to provide awareness in the development of the Subang Batik Tourism Village as an alternative to meet needs, increase the level of 
welfare, and be able to adapt to the acceleration of sociocultural transformation.

The instrumental objective of the training model for the formation of innovative attitudes is to fulfill the learning needs of KPPMK members for the gaps in existing knowledge to develop the expected Subang Batik Tourism Village. This objective is specifically an effort to develop participatory learning activities for KPPMK members in the process of knowing, interested, assessing, experimenting, accepting and integrating training programs so that innovative members are formed. To arrive at the findings of the final model, this study was carried out through preliminary studies and effectiveness studies.

TABLE II. THE SigNIFICANCE TEST OF KRUSKAL WALLIS DiFFERENCES IN PERSONALITY VARIABLES AgAINST CHARACTERISTICS OF RECIPIENTS OF INNOVATION

\begin{tabular}{|c|c|c|c|c|}
\hline & & \multirow{2}{*}{$\begin{array}{c}\text { Characteristics of } \\
\text { Recipients of } \\
\text { Innovations }\end{array}$} & \multicolumn{2}{|c|}{$\begin{array}{l}\text { There is a } \\
\text { difference }\end{array}$} \\
\hline & & & Yes & No \\
\hline \multirow[b]{2}{*}{ Demographics } & Generation & 0,6 & & $\mathrm{~V}$ \\
\hline & $\begin{array}{l}\text { Number } \\
\text { Children }\end{array}$ & 0,4 & & $\mathrm{~V}$ \\
\hline \multirow{2}{*}{ Social } & Marital Status & 0,3 & & $\mathrm{~V}$ \\
\hline & Education & 0,0 & $\mathrm{~V}$ & \\
\hline \multirow{4}{*}{ Economy } & Profession & 0,4 & & $\mathrm{~V}$ \\
\hline & $\begin{array}{l}\text { Length } \\
\text { Business }\end{array}$ & 0,8 & & $\mathrm{~V}$ \\
\hline & Dependents & 0,4 & & $\mathrm{~V}$ \\
\hline & Income & 0,0 & $\mathrm{~V}$ & \\
\hline
\end{tabular}

Based on Table 2, the personality variable in the form of generation has no difference to the characteristics of the recipient of the innovation as indicated by a significance value of 0.6 , more than 0.05 . This means that the recipients of innovation can occur in various generations, both Generation $\mathrm{X}, \mathrm{Y}$, and $\mathrm{Z}$. Although it needs further investigation, the length of adoption of each generation should be.

Similarly, the group indicated the number of children with probability level 0, 4 against Recipient Characteristics of Innovation, above 0.05 , which means that $\mathrm{H}_{0}$ is rejected. That is, members of KPPMK without children or with children have opportunities and opportunities alike in adopting innovations.

The probability level figure for the marriage group shows and 0,3 on the Characteristics of Recipients of Innovations which means that there is no difference between the groups of respondents who are not married and married to the Characteristics of Recipients of Innovation

In the education group, the probability level is 0 , which means that $\mathrm{H}_{0}$ rejected because it is below 0.05 . This shows that there are differences between the basic education, high school, and undergraduate groups on the characteristics of the recipient of the innovation. These findings support Al-Zubeidi's [8] presentation that education provides two important roles. First, related to expertise in launching different business ideas. Second, educational background plays a role as a person's provision to deal with environmental changes and competition.
The employment status of the Characteristics of Recipients of Innovation is indicated by a probability level of 0.4 , which means that $\mathrm{H}_{0}$ accepted because it is above 0.05. This shows that there is no difference between the unemployed, employees, and business owners on the Characteristics of Recipients of Innovation. This means that each job group can adopt innovations.

The length of work/business for the Characteristics of Recipient of Innovations is indicated by a probability level of 0.8 , which means that $\mathrm{H}_{0}$ accepted because it is above 0.05 . This shows that there is no difference between groups of 0 years of work / business, 1-2 years of work / effort, and more than 2 years of work / effort of the Characteristics of Recipients of Innovation. The income group that reached the UMK reached a higher average score than the income group that did not reach the UMK on the Characteristics of Recipients of Innovation. Income expectations are one of the reasons a woman is entrepreneurial. For married women, entrepreneurship is an effort to improve the economy when household needs are not fulfilled by the husband's income. Meanwhile, for unmarried women, income is one of the motivations for entrepreneurship. Therefore, the group of women who have reached the UMK is in a higher category than those who have not reached the UMK.

The probability level for the category of dependents for the Characteristics of Innovation Recipients is a probability level of 0.4 , which means that $\mathrm{H}_{0}$ accepted because it is above 0.05 . This shows that there is no difference between the groups of respondents who have economic dependents and do not have economic dependents for the Characteristics of Recipients of Innovations.

From the results of these preliminary data, it shows that innovation adoption can be carried out in a wider segment of society by taking into account the differences in education levels and income of members. Higher education and higher income groups can be trained by becoming agents of change who exert influence through communication channels. Meanwhile, other groups as the subject of change agents can develop their innovative attitude which is needed as an intervention that is oriented to facilitate learning needs in overcoming knowledge and skills gaps for the smooth running of KPPMK activities in developing the Subang Batik Tourism Village.

To explore the results of the data obtained, the KPPMK founders were interviewed regarding key factors for adoption and the capacity required by KPPMK members or participants to adopt Subang Batik training. The first finding was that the researchers found that awareness of using knowledge and skills was still limited among KPPMK members. The training that has been held is limited to providing knowledge and skills to make Batik Subang. Does not include knowledge and skills to innovate the development of the Subang Batik Tourism Village. Members need to be told how to access sources of practical knowledge and encouragement for self-study. In addition, the involvement of members during the development 
phase is still very limited. Members are not involved in a number of existing problems. Such as limited access to capital, networks, and batik equipment and equipment. So that the existence of KPPMK is only considered as an additional activity for the members. Not as a joint effort to create a better life through the Subang Batik Tourism Village.

From the respondent's point of view, a time frame is needed to get the benefits of pioneering the Subang Batik Tourism Village. In realizing the Subang Batik Tourism Village, a long series of processes is needed, including the provision of facilities, facilities, infrastructure, quality and consistency of products, and resources. The results of the hard work done are relatively unobtainable. On the other hand, b UKTI innovation is very important as driving factors for adopting [9].

Therefore, Rogers [1] highlights that time is an important factor in the innovation process. The time dimension refers to the length of time it takes an innovation to convince potential adapters to decide whether to be an adopter or a rejecter of an innovation. The process of making an innovation decision is divided into five stages, starting from the first introduction of an innovation to forming attitudes towards it, then decisions to be adopted or rejected, then to the implementation and use of new ideas or practices, and finally confirmation of decisions. At various stages of the decision-making process, individuals seek information in order to reduce uncertainty about the expected innovation results.

From the external aspect, government support is limited to the legality aspect of the batik Subang motif. Meanwhile, to access a number of social assistance programs, KPPMK does not yet have aspects of administrative requirements. As for the private sector, it was hampered by the pandemic conditions.

The differences in recipients of innovation adoption and the problems that exist in the field cause innovative youth training models to be adjusted. In the use of innovative learning methods [10], should pay attention to collaborative activities and reflection. Second, learning is designed to help participants understand the concept of knowledge through practical experience of empirical learning. Third, the learning community fostering model, which is a consortivist method that positions the instructor as a facilitator in uncovering relevant theories in response to student questions. Fourth, the High-Level Thinking Skills Method [11], which is a method used to explore problems faced by students and then discuss them in a discussion with objectives and action plans to solve them. Fifth, flipped classrooms (Circa, A. 2007 in Leslie, D. [11]), which is an interactive learning method by uploading online material for student review before entering class. Sixth, learning by design is a research-based learning curriculum to analyze several cases, so that students can solve various problems, then determine their own way to be used in the field. Seventh, direct instruction, aims to develop and stimulate learning through direct instruction that can be understood and written directly by teachers with high levels of student achievement in framed exercises targeted at the dynamic involvement of each student with low errors.

\section{CONCLUSION}

This study identifies personality variables and examines the differences in the characteristics of innovation recipients using an exploratory qualitative research approach. Data were collected by questionnaire to 18 respondents as KPPMK members and interviewing the founders and initiators of KPPMK. The purpose of this approach is to look at the topic of adoption using a broader perspective on which to design Innovative Youth Training.

The main results show that from the social side, education holds the difference from the adoption of innovation. Higher education tends to lead to better adoption. From an economic point of view, the income of KPPMK members that reaches above the Regional Minimum Wage shows better adoption compared to KPPMK members whose income has not reached the Regional Minimum Wage.

From the results of the interview, several information was obtained that caused the development of the Subang Batik Tourism Village to be delayed. The training conducted so far is an expected need which results in reduced participation of participants, awareness, access to knowledge, skills, capital, and networks. In addition, it was found that KPPMK members had not seen the benefits of innovation, making adoption difficult.

\section{ACKNOWLEDGMENT}

The authors appreciate the financial support offered by NUFFIC and other support provided by the Directorate of Research and Community Service, Directorate General of Research and Development, Ministry of Research, Technology and Higher Education of the Republic of Indonesia. Also, grateful to KPPMK for providing access to this research so that it can run.

\section{REFERENCES}

[1] M. Dibra, "Rogers Theory on Diffusion of Innovation - The Mos Appropriate Theoretical Model in the Study of Factors Influencing the Integration of Sustainability in Tourism Businesses". Procedia - Social and Behavioral Sciences. 195, pp. 1453-1462. 2015.

[2] A. Nasrullah, Nanas dan Padi Dipatenkan dalam Motif Batik Khas Subang. [Online] Retrieved 2020, September 1 from: http://www.tintahijau.com/megapolitan/ekbis/14148-nanas-dan-padidipatenkan-dalam-motif-batik-khas-subang, 2018.

[3] I. Saripah, "Implementasi Pelatihan Kewirausahaan Bagi Anak Putus Sekolah”. Jurnal AKRAB, Volume V Edisi 1/Juni. 2017.

[4] E.M. Rogers, Diffusion of Innovations. New York: A Division of Macmillan Publishing Co., Inc. 1971.

[5] Sugiyono. Metode Penelitian Kuantitatif, Kualitatif, dan R\&D Bandung: Alfabeta. 2013

[6] E. Ardianto, Metodologi Penelitian untuk Public Relations: Kuantitatif dan Kualitatif. Bandung: Simbiosa Rekatama Media. 2014.

[7] M.D. Myers, "Qualitavive Research in Infomation Systems". MIS Quarterly, Vol. 21 No 2, pp. 214-242. 2017.

[8] M. Al-Zubeidi, Higher Education and Entrepreneurship: The Relation Between College Educational Background And All Business Success in Texas. Disertasi: University of North Texas. 2005

[9] M.P. Senyolo, T.B. Long, V. Blok, and O. Omta, "How the characteristics of innovations impact their adoption: An exploration of 
climate-smart agricultural innovations in South Africa". Journal of Cleaner Production, 172, 3825-3840. 2018. doi:10.1016/j.jclepro.2017.06.019

[10] R.D. Lestari and I. Saripah, "Strengthening Cultural Values Through Innovative Learning of Sunda Siger Bridal Makeup in West Java
Vocational Education". Andvances in Social Sciece, Education and Humanities Research, Volume 419, p. 222-229, 2019. https://doi.org/10.2991/assehr.k.200321.053.

[11] D. Leslie, Innovative Learning. Finlandia: HAMK University. 2015. 